\title{
Türkiye' de Kayıt Dışı İstihdamın Boyutu: Ekonometrik Bir Analiz
}

\author{
M. Metin Dam ${ }^{1} \quad$ Şaban Ertekin $^{2} \quad$ Nurullah Kızılca $^{3}$
}

\begin{abstract}
$\ddot{O}_{z}$
Bu çalışmada, Türkiye’nin 2002-2016 dönemi ekonomik büyüme, işsizlik ve enflasyonun kaylt dışı istihdam üzerindeki etkileri Genişletilmiş Dickey-Fuller birim kök testi $(A D F)$ ve en küçük kareler yöntemi (EKK) ile analiz edilmiştir. Analizden elde edilen ampirik bulgulara göre; işsizlik değişkeninin katsayısı pozitif ve istatistiksel olarak anlamlı bulunmuştur. Enflasyon değişkeni katsayısı da pozitif iken istatiksel olarak anlaml bulunmamıştır. Diğer taraftan ekonomik büyüme değişkeninin katsayısı negatif elde edilmesine ră̆men istatistiksel olarak anlamlı değildir. Analiz sonucunda; işsizlikteki $\% 10$ 'luk artışın kayıt dışı istihdamı \%4 oranında arttırdı ̆̆ tespit edilmiştir.
\end{abstract}

Anahtar Kelimeler: Kayıt Dışı Ekonomi, Kayıt Dışı Istihdam, Ekonomik Büyüme, İssizlik, Enflasyon, Zaman Serisi Analizi.

JEL Sinıflandırma Kodları: O32, O40, F43, C33.

\section{The Extent of Informal Employment: An Econometric Analysis}

\begin{abstract}
In this study, the effects of economic growth, unemployment and inflation on the informal employment is analyzed by using Augmented Dickey-Fuller unit root test (ADF) and least square method for the years between 2002 and 2016 in Turkey. Empirical results of the analysis show that, the coefficient of employment variable is positive and statistically significant. The coefficient of inflation variable is also positive, but it is not statistically significant. On the other hand, the coefficient of economic growth variable is negative and statistically insignificant. The results of the study reveal that a $10 \%$ increase in unemployment leads to a $4 \%$ increase in the informal unemployment.
\end{abstract}

Keywords: Informal Economics, Informal Employment, Economic Growth, Unemployment, Inflation, Time Series Analysis.

JEL Classification Codes: O32, O40, F43, C33.

\footnotetext{
${ }^{1}$ Dr. Öğr. Üyesi, Adnan Menderes Üniversitesi Nazilli İktisadi ve İdari Bilimler Fakültesi, Uluslararası Ticaret ve Finansman Bölümü, metindam@hotmail.com

2 Dr. Öğr. Üyesi, Adnan Menderes Üniversitesi, Aydın İktisat Fakültesi, Maliye Bölümü, saban.ertekin@adu.edu.tr

3 nurullahkizilca@gmail.com
} 


\section{GíRİş}

$$
\text { M.M.DAM - Ş.ERTEKIN - N.KIZILCA }
$$

Kayıt dışı ekonomi, genel çerçevede kamu otoritelerinin bilgisi ve denetimi dışında yer alan her türlü ekonomik işlemler şeklinde tanımlanabilir. Bu tür işlemler, üretim faktörlerinden sermaye üzerinde olabildiği kadar emek faktörü için de söz konusu olabilmektedir. Nitekim kayıt dışı ekonomi, çalışma hayatı bağlamında sosyal güvenlik yasalarına aykırı işçi çalıştırılması şeklinde karşımıza çıkmaktadır. Dolayısıyla kayıt dış1 istihdam, bir ülkede çalışmakta olan nüfusun resmi istihdam göstergelerine yansıtılmayan kısmı olarak tanımlanabilir. Ayrıca ilgili mevzuata göre bildirilmesi zorunlu olduğu halde bildirilmeyen istihdam da dar anlamda kayıt dışı istihdam olarak adlandırılmaktadır (Bağırzade, 2012:214).

Kayıt dışı ekonominin hacmi son 30-40 yıl içinde başta az gelişmiş ve gelişmekte olan tüm ülkelerde önemli boyutlara ulaşmıştır. Elbette doğası gereği, kayıt dışı ekonominin gerçek boyutunu tahmin etmek mümkün olmamaktadır. Buna karşın çeşitli analizler ile bazı tespitler yapılabilmektedir. Ancak, ülkeler arasında hesaplamalarda kullanılan tahmin yöntemleri ve tanımlamada kullanılan bazı kavramlar açısından farklılık ortaya çıkabilmektedir. Bu farklılığa yol açan etkenler olarak kayıt dışı ekonomik faaliyetler dışında sosyal, siyasi, ahlaki ve psikolojik unsurların da etkili olduğu ifade edilebilir.

Çalışmanın amacı, ekonomik büyüme, işsizlik ve enflasyondaki değişimin teorik çerçeve dahilinde kayıt dışı istihdam etkisini incelemektir.

Çalışmada öncelikli olarak kayıt dışı ekonomi kavramı, nedenleri ve sonuçları ile kayıt dışı istihdam şekilleri, kayıt dışı istihdamın etkileri ile Türkiye'deki kayıt dışı istihdamın görünümü incelenmiştir. Çalışmanın 
Dokuz Eylül Üniversitesi İktisadi ve İdari Bilimler Fakültesi Dergisi Cilt:33, Sayl:1, Yll:2018, ss. 293-318

sonraki bölümlerinde ise literatür özetine yer verilerek ekonometrik analiz gerçekleştirilerek çalışma sonuç ve değerlendirme ile tamamlanmıştır.

\section{KAYIT DIŞI EKONOMI KAVRAMI}

1970’li yıllardan itibaren üzerinde durulmaya başlanan kayıt dış1 ekonomi kavramı konusunda araştırmacıların kabul ettiği ortak bir tanım bulunmamaktadır. Buna karşın kayıt dışı ekonomi; gayri safi milli gelir hesaplarını elde etmede kullanılan ve bilinen istatistik yöntemlerine göre tahmin edilemeyen, vergi ve diğer kanunlardan kaçmaya yönelik beyan edilmeyerek kayıtlara geçmeyen gelir yaratıcı ekonomik faaliyetler olarak tanımlanabilir (Kızılot ve Çomaklı, 2004:12). Ayrıca kayıt dışı ekonomi kavramı yerine aynı anlamı ifade eden gizli ekonomi (hidden economy), elalt1 ekonomisi (clandestine economy), paralel ekonomi (parallel economy), görünmez ekonomi (invisible economy)) gölge ekonomi, illegal ekonomi, beyan dışı ekonomi gibi bir dizi kavram kullanılabilmektedir (Önder, 2001:241). Kayıt dışı ekonomi ülkelerin gelişmişlik düzeyleri yakından ilişkili olup, günümüz ekonomilerinde istihdam, demografik yapı, vergi yükü, ekonomik büyüme, işsizlik gibi birçok makroekonomik değişken üzerindeki etkileri nedeniyle çözülmesi gereken karmaşık ve çok yönlü bir konudur.

Bir faaliyetin kayıt dışı olarak nitelendirilebilmesi için fiilen gerçekleşmiş ekonomik faaliyetlerin kayıtlarının tutulmaması ya da eksik tutulması aynı zamanda kamu idarelerinin denetimi dışında kalması gerekmektedir (Sarıl1, 2002:45). Ekonomik faaliyetlerin kayıtlarının tutulmaması ya da eksik tutulması ekonomik büyüme, işsizlik, gelir dağılımı gibi makro ekonomik değişkenlerin doğru tespit edilememesi ve ekonomik sorunlarla mücadele konusunda doğru teşhisin konulmasına neden olacaktır. 


\section{M.M.DAM - Ş.ERTEKIN - N.KIZILCA}

Sonuç olarak yeni strateji ve politikaların belirlemesini güçleştirecektir (Önder, 2001:242).

Kayıt dışı faaliyetlerin denetlenmesi ve kontrolündeki güçlükler nedeniyle, genellikle tarım ve hizmet sektörlerinde daha çok rastlanılmaktadır. Kayıt dışı faaliyetlerin ekonomiye olumlu ve olumsuz etkileri olabilmektedir. Kayıt dışı yelpazesi muhtelif faaliyetleri çatısı altına alan, bir yönüyle de vergilemeden kısmen veya tamamen kaçırılan işlemlerdir. Kayıt dışı ekonomi doğası gereği gizlilik, hacminin büyüklüğü tahminlerinde ve buna ilişkin denetimlerde zorluklar oluşturmaktadır (Y1lmaz, 2006:211).

Kayıtdışı ekonominin oluşum nedenleri inceleme konusu yapıldığında ülkelerin siyasi, kültürel, hukuki, ahlaki değerleri ve gelişmişlik düzeylerinin ön plana çıktığı görülmektedir. Öyle ki kayıt dışılık gelişmiş bir ekonomi açısından daha çok vergisel yükten ötürü ortaya çıktığı, buna karşın gelişmekte olan ülkelerde ise daha ziyade demografik değişimden ya da gelir dağılımındaki adaletsizlikten kaynaklandığı söylenebilir. Yani ekonomik yapıları güçlü ve kurumsallaşmış ülkelerde kayıt dışı ekonominin boyutunun çok düşük olduğu görülmektedir. Ülkeden ülkeye farklılık arz etmekle birlikte kayıt dişı ekonominin ortaya çıkma nedenlerinin başında iktisadi ve mali nedenlerin geldiği bilinmektedir (Candan, 2007:9). Toplumda bireyler daha fazla gelire sahip olmak adına, ekonomik faaliyetlerinin tümünü veya bir kısmını kayıt dışında tutarak bu faaliyetlerden elde ettikleri kazançları üzerinden vergi ödememektedir. Sonuçta vergi ödeyen mükelleflerden daha fazla harcanabilir gelir elde etmiş olmaktadırlar (Sarıl1, 2002:38).

İşsizlik ve vergi oranlarının yüksekliği, ücret gelirleri üzerindeki mali yük, vergi denetimindeki etkinsizlik, sıklıkla başvurulan mali aflar ve af 
beklentileri, mali mevzuatın karmaşık yapısı kayıt dışı ekonominin başlıca sebepleri arasında gösterilebilir. Ayrıca nüfus artışı ile birlikte, metropol niteliği kazanan yerleşim yerleri ortaya çıkan sorunlar giderek ağırlaşmakta, bu durum yeni değer yargılarının oluşmasına ve yasalara itaat eğiliminin azalmasına yol açmaktadır (Candan, 2007:9).

Kayıt dışı ekonomik faaliyetlerin gizlilik içerisinde yürütülmesi nedeni ile kayıt dışı ekonominin boyutunu ölçmek oldukça güç olmakla birlikte, Gayrisafi Milli Hasıla Yaklaşımı, Ekonometrik yaklaşım, Anket yolu gibi farklı yöntemlerle tespit edilmesi mümkündür.

Kayıt dışı ekonomideki oransal artış, kamu giderlerinin en önemli finansal kaynağı olan vergi gelirlerindeki azalma ya da vergi yükündeki artışa sebep olacaktır. Bu sonuç kamunun borçlanma yada para basma (emisyon) eğilimlerini artırarak enflasyon, faiz, gelir dağılımındaki adaletsizlik gibi yeni ekonomik olumsuzluklara sebep olabilecektir. Kayıt dışı ekonominin, sadece olumsuz sonuçları değil aynı zamanda ekonomik yaşam ve bireyin refahına pozitif katkılar sağlayabileceği de ileri sürülmektedir. Özellikle kayıt dışının yaygın olduğu faaliyet alanlarında, işletmelerin kayıt dışı nedeniyle ellerinde biriken fonlarını yeni yatırımlara ve istihdama kanalize edebileceklerdir. Bu bağlamda; fonlar kamu kesimi yerine özel kesim tarafindan kullanılarak ekonomiyi daha yüksek bir verimlilik düzeyine taşıyorsa, o durumda kayıt dışının ekonomiye zarardan ziyade fayda sağladığı da ileri sürülebilmektedir (Aydemir, 1995:95).

\section{KAYIT DIŞI İSTIHDAM KAVRAMI}

Kayıt dışı istihdam, ilk defa 1970 yılında Uluslararası Çalışma Örgütü tarafindan düzenlenen Dünya İstihdam Programı (World Employment Program) kapsamındaki Kenya Raporunda “enformel sektör” şeklinde kullanılmıştır (Güloğlu, 2005:2). Söz konusu rapora göre kayıtlı ekonomi 


\section{M.M.DAM - Ş.ERTEKIN - N.KIZILCA}

tarafından giderilemeyen işsizliğin, kayıt dışı ekonomi ya da sektörler tarafindan absorbe edildiği ifade edilmiştir.

Kayıt dışı istihdam konusunda çeşitli tanımlara yer verilebilir. Nitekim kayıt dışı istihdam bir tanıma göre istihdam faaliyetlerinin resmi belgelere yansımaması ya da gerçekleştirilen istihdam süresi ve ödenen ücret miktarının resmi makamlara eksik bildirilmesidir (Mahiroğulları, 2017:548). Diğer bir tanıma göre sosyal güvenlik açısından niteliği itibariyle yasal işlerde çalışarak istihdama katılan kişilerin, çalışmalarının gün veya ücret olarak ilgili kamu kurum ve kuruluşlarına ya hiç bildirilmemesi ya da eksik bildirilmesi olarak tanımlanabilir (SGK, 2017). Bir başka tanıma göre ise kayıt dışı istihdam; resmi makamların bilgisi dışında işçi çalıştırma (Altuğ, 1999:11) veya bir kişinin bir iş sözleşmesi olmadan ve ne zamana ve ne kadar ücret alacağının bildirilmeden çalıştııılmasıdır. (Candan, 2007:14).

Görüldügü üzere kayıt dışı istihdam kayıt dışı ekonominin çalışma hayatındaki karşılığı ya da işgücü piyasasında görülme şekli olarak ifade edilebilir. Bu bağlamda kayıt dışı istihdam; çalışanların ücret ve prim gün sayılarına ait bildirimi zorunlu verilerin vergi daireleri ya da sosyal güvenlik kurumu gibi kamu idarelerine bildirilmemesi veya eksik bildirilmesi yahut zamanında bildirilmemesi şeklinde ortaya çıkmaktadır.

\subsection{Kayıt Dışı İstihdamın Nedenleri}

Kayıt dışı istihdam düzeyinin yüksek olduğu ülkeler genellikle enflasyonun yüksek seyrettiği, gelir dağılımının adaletsiz ve ekonomik denetimlerin etkin yapılamadığı gelişmekte olan ülkelerdir (Fidan ve Genç, 2013:140). Bu sebeple bir ülkede kayıt dışı istihdamın ortaya çıkmasına sebep olan işçi ve işveren ait özel sebepler olsa da, makro anlamda gelişmişlik düzeyleri ile birlikte, idari ve bürokratik nedenler, ekonomik ve 
mali nedenler, sosyal ve kültürel nedenler önemli rol oynamaktadır. $\mathrm{Bu}$ anlamda kayıt dışı istihdamın nedenleri aşağıdaki gibi sıralanabilir:

\subsection{Ekonomik ve Mali Nedenler}

Kayıt dışı istihdamın nedenlerinin başında ülkelerin ekonomik ve mali yapısı gelmektedir. Bireyleri kayıt dışılığa yönlendiren ekonomik nedenlerin başında ise daha fazla kazanma arzu ve isteği gelmektedir. Özellikle işverenlerin üretim maliyetlerini düşürerek daha fazla kazanç elde etme güdüsü onları kayıt dışılığa yöneltirken, çalışanlar ise işsiz kalmamak ve kısmen de olsa daha fazla kazanç elde etme adına kayıt dışı istihdama rıza gösterebilmektedir. Özellikle enflasyonist ortamlarda gelecekle ilgili satın alma gücündeki belirsizlikler, müteşebbislerin yatırım ve istihdam kararlarını olumsuz etkileyerek işsizliğe ya da kayıt dışı istihdama sebep olabilmektedir. Tarım kesiminin ekonomi içerisindeki payı, gelir ve kaynak dağılımındaki adaletsizlik ve bunun ortaya çıkarmış olduğu yoksulluk, işsizlik oranındaki artışlar, ülkedeki küçük ve orta ölçekteki işletme sayısı, küçük işletmelerin rekabet güçleri gibi nedenler kayıt dışı istihdam oranını etkileyen önemli ekonomik faktörlerdir.

Ülkelerin vergi sistemleri, mali denetim eksikliği, ağır vergi yükü ve siyasal yapı gibi nedenler ise kayıt dışı istihdama sebep olan mali ve idari faktörler arasında sayılabilir (Fidan ve Genç, 2013:38). Bunun için işverenler ya istihdam edilenlere ödenen maaş vb. ödemeleri resmi kayıtlarının dışına çıkarak vergi diğer sosyal güvenlik primlerinden kurtulma yolunu ya da fiilen ödenen tutarın kayıtlarda daha düşük gösterilerek daha az vergi ve diğer sosyal güvenlik prim ödemelerini düşürme yoluna gitmektedirler. Ancak halen devletin aldığı vergi ve prim oranları yüksektir. Örnek olarak 2017 yılında 1.404 TL çalışana ödenen net asgari ücret tutarının işverene maliyeti $2.088 \mathrm{TL}$ olup, asgari ücretin \%67'si 
M.M.DAM - Ş.ERTEKİN - N.KIZILCA

işçiye ödenirken, \%33'lük kısım kamuya vergi sosyal güvenlik primi olarak aktarılmaktadır.

Sonuç olarak ülkelerin istihdam üzerindeki mali yük, kayıt dışı istihdamın artmasında son derece etkilidir. Sıklıkla değişen mali mevzuat, mevzuattaki karmaşık yapı, vergi kanunlarındaki muafiyet ve istisnaların sayısı, ücret gelirleri üzerindeki vergi yükü, sosyal güvenlik prim ödemeleri, mali konulardaki denetim eksiliği, bir işçinin işverene maliyeti gibi sebepler kayıt dışı istihdamı tetikleyen mali unsurlardır.

\subsection{Sosyal ve Kültürel Nedenler}

Ekonomik ve mali nedenlere ilave olarak kayıt dışılığa zemin hazırlayan diğer bir sebep ise sosyal ve kültürel nedenlerdir. Ülkenin sahip olduğu eğitim ve sağlık sistemi, demografik yapı, köyden kente göçlerdeki artış ve sonucunda ortaya çıkan çarpık kentleşme, nüfus artış hızının sebep olduğu işsizlik kayıt dışı istihdamı önemli ölçüde artıran nedenlerdendir. Emek piyasasındaki istihdam olanaklarının hızla artan nüfusu karşılamayışı ve bu çerçevede gelişen köyden kente hızlı göç ve çarpık kentleşmenin sonucu olarak niteliksiz işgücü ve emek sahiplerinin daha az ücretle ve sosyal güvenceye sahip olmaksızın çalışmaya razı olması sonucunda ortaya çıkan kayıt dışı ekonomik faaliyetler olduğu görülmektedir (Us, 2004:10).

Özellikle kırsal kesimde yaşayanların eğitim seviyesinin düşüklüğü, tarımsal üretimdeki etkinlik ve verimlilik düşüklüğü ve hızlı nüfus artışı kırdan kente göçü zorunlu hale getirmiştir. Kırsal kesimlerde tarımda istihdam edilen çocukların düşük ücret ve kayıt dışı çalıştırılmaları çok sık rastlanılan bir durumdur. Kentlerde ise ayakkabı boyacılığı, yollarda araba camı silme, gazete ve su satıcılığı gibi marjinal işlerde yoğun çocuk istihdamı ile karşılaşılmaktadır. Sonuç olarak ülkemizde çoğu çocuklar hiçbir yasal güvence ve sosyal güvenlik sisteminin korumasından 
yararlanmadan, eğitim çağlarında yoğun bir şekilde ucuz işçi olarak çalıştırılmaktadır (Candan, 2007:36)

\section{4. İdari ve Bürokratik Nedenler}

Kayıt dışı istihdamın önemli nedenlerinden birisi de idari ve bürokratik nedenlerdir. Özellikle ülkemizde bir işletme açmak için işin mahiyetine göre yerel ya da merkezi idareye bağlı birçok farklı kurumdan izin alınması gerekmektedir. $\mathrm{Bu}$ durum işletmelerin kuruluş ve işletme maliyetlerini artırmakta ve kayıt dış1lığı özendirmektedir. Türkiye'de iş kurma süreçleri uzun olmakla birlikte iş için harcanan maliyet kişi başına düşen gelirin \%11,2'si kadardır (Kamalıŏlu, 2014:52).

Vergi ve sosyal güvenlik mevzuatı ile çalışma hayatını düzenleyen kanunların uzun ve karmaşık yapısı kayıt dışı istihdama zemin hazırlamaktadır. Özellikle kanunların sıklıkla değişmesi, bireylerin ötesinde konunun uzmanlarının bile zorlandığı bir sorun olmaktadır. Kayıt dışı istihdama sebep olan bir diğer bir unsur etkili ve düzenli bir denetim faaliyetinin olmamasıdır. İşletmelerin geçmiş dönemlerde yapmış oldukları işlemlerin ve faaliyet dönemlerine ait işlemlerinin etkin bir şekilde denetlenememesi kayıt dişı ekonomik faaliyetlerin artmasına neden olmaktadır (Candan, 2007:53). Bu durum çalışma hayatını düzenleyen bakanlıklar ve kurumlar arasındaki iletişim ve koordinasyon eksikliği ile bireylerin vergi ödeme bilinci ve kayıt dışı istihdam üzerinde etkili olmaktadır. Tahsil edilen vergilerin uygun olarak kullanılmadığı yönünde oluşan alg1 veya bireylerin kamu idarelerine olan güvensizlik duygusu kayıtdışılığı artırmaktadır.

\subsection{Kayı Dışı İstihdam Şekilleri}

Kayıt dışı istihdam birçok şekilde yapıldığı gibi bildirim eksikliği şeklinde de uygulanmaktadır. Bildirim eksikliği sadece çalışılan süre ile 


\section{M.M.DAM - Ş.ERTEKIN - N.KIZILCA}

ilgili olmayıp, yaygın olarak prime esas kazancın daha eksik gösterilmesi şeklinde görülmektedir. Yüksek ücret elde edenlerin daha az vergi ve sosyal güvenlik primi ödemek için, bildirimlerini asgari ücret üzerinden kayıtlarda göstermesi yaygın kullanılan bir yoldur. Kayıt dışılık, müteşebbislerin zorlaması şeklinde olabileceği gibi istihdam edilenlerin kendi istekleri sonucunda da görülebilir. Özellikle kaçak ve çocuk işçiler gibi kanunun çalışmasına izin vermediği gruplarla, sosyal güvenlik kurumlarından işsizlik ödeneği, dul-yetim maaşı gibi çeşitli şekilde sosyal yardım alanlar, yardımların kesilmemesi için gönüllü olarak kayıt dışı istihdama göz yummaktadırlar.

\subsection{Kayıt Dışı İstihdamın Etkileri}

Kayıt dışı istihdam kavramı genel olarak olumsuz bir algı oluşturmakla birlikte, ekonomik ve sosyal yaşam içerisinde olumlu ve olumsuz etkilere sahip olduğu tespit edilmiştir. Kayıt dışı istihdamın en önemli olumsuz etkisi vergi gelirleri ve sosyal güvenlik prim ödemeleri nedeniyle kamu gelirleri üzerinde olacaktır. Kamu gelirlerinde söz konusu azalma, sosyal güvenlik açıklarına ve bütçe üzerinde olumsuz bir etkiye sebep olacaktır. Bütçe açıklarının borçlanma yoluyla karşılanması sonucu artan faiz oranları nedeniyle kamu borçlanma maliyeti de artmakta dolayısıyla bütçe açıkları daha da artmaktadır. Bütçe açıklarının para basılarak kapatılmaya çalışılması ise, enflasyon oranın yükselmesine ve dolayısıyla gelir dağılımının daha da bozulmasına neden olmaktadır (Sarılı, 2002:43). Kamu giderlerinin borçlanma ve emisyon ile finansmanı ise gelir dağılımı ve ekonomik büyümeyi olumsuz etkileyecektir.

Bireyler açısından değerlendirildiğinde ise kayıt dışı iş sağlığı ve güvenliği, iş kazaları ve meslek hastalıkları gibi sağlık sorunları ile emeklilik, kıdem ve ihbar tazminatı gibi sosyal haklar konusunda önemli 
Dokuz Eylül Üniversitesi İktisadi ve İdari Bilimler Fakültesi Dergisi Cilt:33, Sayl:1, Yll:2018, ss. 293-318

mağduriyetlere sebep olabilmektedir. Kayıt dişı istihdam kaçak işçi ve çocuk işçi sayısında artışa, emeğin sömürülmesine, işçilerin verimliliklerinin düşmesine, bireylerin ve ailelerin gelecek kaygılarının artmasına, sendikalaşma eğilimlerinin düşmesine sebep olabilmektedir.

Kayıt dışı istihdam kavramı ifade edildiğinde genel olarak olumsuz bir alg1 oluşturmakla birlikte üretim, istihdam ve özellikle emek piyasası üzerinde olumlu etkileri olduğu tespit edilmiştir. Kayıt dışı faaliyette bulunan firmaların kayıt dişılık nedeniyle vergi ve benzeri mali yükümlülükleri yerine getirmeyerek kendilerine üretim maliyetleri açısından rakipleri karşısında avantaj sağlamaktadır (Altuğ, 1999:483). Bu sonuç özellikle istihdam, gelir dağılımı, firmaların piyasalarda rekabet gücü, kaynak dağılımı gibi konularda olumlu etkiler yaratmaktadır.

\subsection{Türkiye'de Kayıt Dışı İstihdamın Genel Görünümü}

Kayıt dışı istihdam özellikle gelişmekte olan ülkelerde toplam istihdam içinde önemli bir paya sahiptir. Gelişmekte olan ülkelerde kentleşme, göç ve nüfus artması ile değişen demografik yapı zemininde yoksulluğun ve yeni yoksulluk olgusunun ortaya çıkmasına sebep olmaktadır. Özellikle küreselleşme ile birlikte üretim ve işgücündeki yapısal değişimler dünya genelinde istihdamı olumsuz etkileyerek işsizlik sorunun kronikleştirmiş ve kayıt dışı çalışmayı kolaylaştırmıştır (İpek, 2014:167). Gelişmekte olan ülkeler kategorisinde bulunan Türkiye’de kayıt dışı istihdamın yoğun olarak gözlemlendiği bir ülkedir. Özellikle 1980’li yıllardan sonra köyden kentlere doğru yaşanan yoğun göçün kayıt dışı istihdam üzerinde etkili olduğu söylenebilir. 2000'li yıllara kadar geçen 20 yıllık süre zarfında kayıt dışı istihdam \%60 gibi oldukça yüksek bir oranda seyretmiştir (Akgeyik vd., 2004:25). 
M.M.DAM - Ş.ERTEKIN - N.KIZILCA

Toplam istihdam içinde tarım sektörünün son 10 yılda \%20-30 gibi oldukça yüksek düzeylerde bulunması kayıt dışı istihdamın bu denli yüksek olmasının önemli bir nedenini oluşturmaktadır. TÜİK tarafindan 2015 yılında yayınlanan son hane halkı iş gücü raporunda tarım sektörünün toplam istihdam içindeki payının \%18,7 olarak gerçekleşmiş ve kayıt dışı istihdam oranları da buna paralel olarak azalma eğilimi göstermiştir (TÜİK, 2015).

Türkiye'de kayıt dışı istihdamın yapısı hakkında bilgi verebilecek çalışmalardan başlıca TÜİK tarafindan yapılan hane halkı İşgücü Anketidir. Çalışmanın bu bölümünde 1989-2015 dönemi için TÜİK Hane Halkı İşgücü Anketleri incelenecek, ancak detay bilgiler için en güncel anket verisine ulaşılamaması halinde eski anketler dikkate alınacak, ayrıca bölüm içinde diğer kurum ve araştırmacıların yapmış oldukları analizlere de yer verilecektir. Hane Halkı İşgücü Anketlerindeki sosyal güvenlik kuruluşlarına kayıtlı olmayan istihdam, bu çalışmada kayıt dışı istihdam olarak kabul edilmektedir. Kayıt dışı istihdamla ilgili ayrıntılara geçmeden önce burada karşılaşılan önemli bir sorundan bahsetmekte fayda görünmektedir. Hane Halkı İşgücü Anketlerinde yer alan kayıtlı istihdam rakamları ile sosyal güvenlik kuruluşlarının kayıtlarında yer alan istihdam rakamları analiz edildiğinde aralarında önemli farklar olduğu görülmektedir. Örneğin sosyal güvenlik kuruluşlarının kayıtlarında yer alan kayıtlı istihdam rakamı 2005 yılı itibarıyla Hane Halkı İşgücü Anketinde yer alan kayıttı istihdam rakamından 2,3 milyon kişi daha yüksektir. 
Dokuz Eylül Üniversitesi İktisadi ve İdari Bilimler Fakültesi Dergisi Cilt:33, Sayl:1, Yll:2018, ss. 293-318

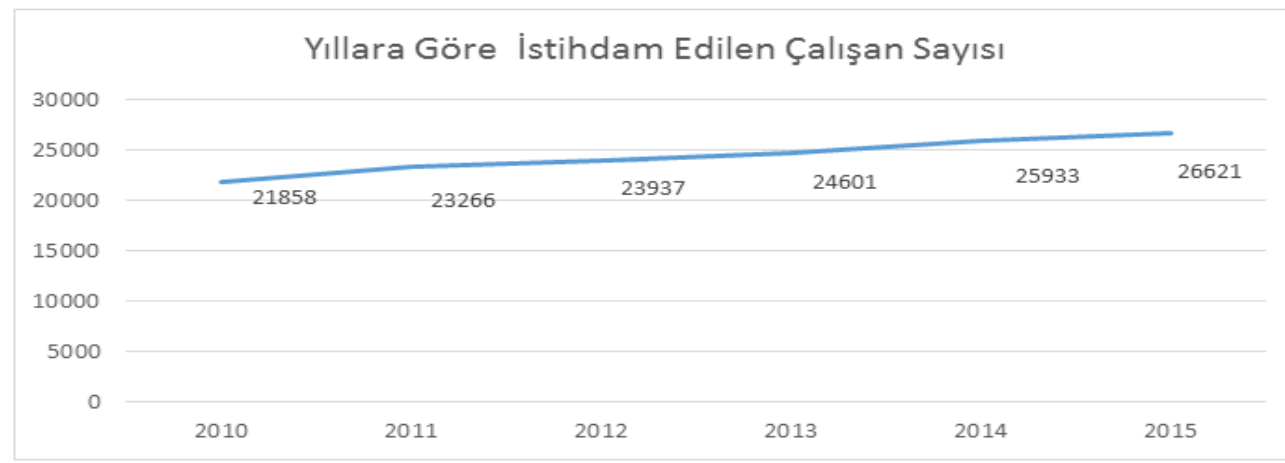

Şekil 2.1. Türkiye'de İşgücü İstatistikleri-İstihdam Edilenler (Bin Kişi)

Kaynak: TÜİK İstatistikleri 2015.

Şekil 2.1'deki Türkiye'de İstihdam Edilenlere ait istatistiklerde görüldüğü üzere iş gücü fazla olmasına rağmen kayıtlı istihdam edilen sayıdaki rakamların düşük gösterilmesi kayıt dışılığın göstergesi anlamına gelebilir. Yani çalışanların hepsi kayıtlı gösterilmiyor. Fakat yine de 2010 ile 2015 arası yaklaşık olarak 5000 kişinin kayıtlı gösterilmesi kayıt dışının azaldığını göstermektedir.

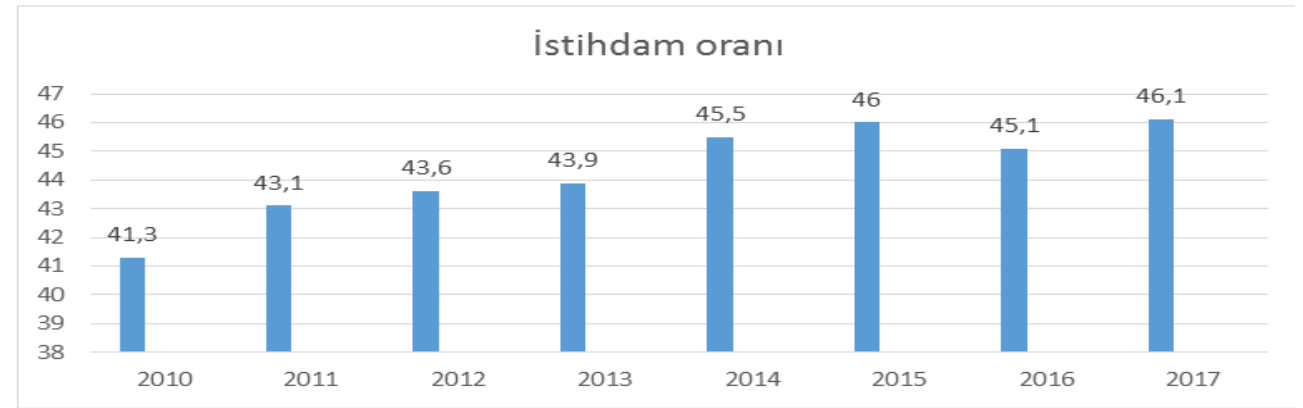

Şekil 2.2. İşgücü İstatistikleri-İstihdam Oranı (Yıllık \%)

Kaynak: TÜiK, 2017.

Şekil 2.1'de Türkiye'de İstihdam Edilenler ile Şekil 2.2'deki İstihdam Oranlarındaki veriler incelendiğinde, istihdam oranlarındaki istikrarlı artış dikkat çekmektedir. 2010 yılında \% 41.3 olarak gerçekleşen istihdam oranı, istikrarlı şekilde artarak 2017 yılında \%46.1 olarak gerçekleşmiştir. Aynı 
M.M.DAM - Ş.ERTEKIN - N.KIZILCA

dönemlerde kayıt dışı istihdam oranlarında ise önemli bir azalma gözlemlenmiştir.

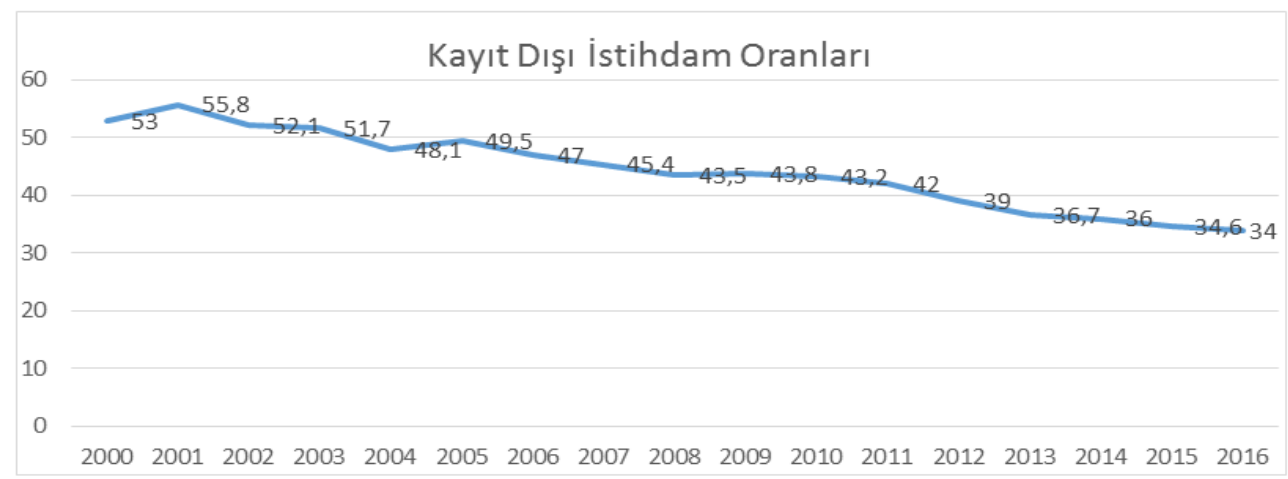

Şekil 2.3. Yıllara Göre Kayıt Dıı̧ı İstihdam Oranları (\%)

Kaynak: TÜiK, 2017.

Şekil 3.3'de Türkiye'de son 16 yıldaki kayıt dışı istihdam oranları gösterilmektedir. 2000 yılında sonraki dönemlerde kayıt dışı istihdam oranlarında istikrarlı şekilde bir azalma olduğu görülmektedir. 2016 yılında TÜİK tarafından yapılan Hane Halkı İşgücü Araştırmasına göre 2000 yılında kayıt dışı istihdam oranı \% 53 olarak tespit edilirken, 2008 yılına gelindiğinde \% 45.8 ve 2016 yılında ise \% 34 olarak tespit edilmiştir. Şekil 3.3'de görüldüğü üzere kayıt dışı istihdamın her geçen yıl düşmesi dikkat çekmekte olup, bunda son dönemlerde uygulanan istihdam politikalarının etkili olduğu söylenebilir.

\section{LITERATÜR ÖZETI}

Literatürde kayıt dışı ekonominin ekonomik büyümeyi olumlu ya da olumsuz yönde etkilediğine dair tam bir görüş birliği bulunmamaktadır. Bazı araştırmacılar kayıt dışı ekonominin büyüme üzerine pozitif bir etkisinin olduğunu savunurken bazıları negatif bir etkisi olduğunu tespit etmişlerdir. Akalın ve Kesikoğlu (2007), 1975-2005 dönemi y1llık verileriyle Türkiye için kayıt dışı ekonomi ile büyüme arasındaki ilişkiyi 
araştırmıştır. Fiege'nin basit ve geliştirilmiş parasal oran yöntemiyle Türkiye’de kayıt dışı ekonominin büyüklüğü tahmin edilmiştir. Elde edilen verilerle ekonomi ile büyüme arasındaki ilişki Granger Nedensellik Analiziyle incelenmiştir. Analiz sonucunda elde edilen bulgulara göre Türkiye'de kayıt dışı ekonominin büyüklüğü basit oran yöntemine göre \%7 ile \%46 arasında, geliştirilmiş oran yöntemine göre ise \%17 ile \%39 arasında olduğu tespit edilmiştir. Nedensellik ilişsisi bulgularına göre kayıt dışı ekonomiden ekonomik büyümeye doğru bir nedensellik ilişkisi bulunmuştur. Son 30 yılda gelişmekte olan birçok ülkede ve geçiş ekonomilerde kayıt dışı ekonominin boyutlarının kayıt altına alınmaya çalışılmasına rağmen hala önemli boyutlarda olduğu kabul edilmektedir. Schneider ve Klinglmair'e (2004:2) göre 2000'li yıllarda kayıt dışı ekonominin Gayri Safi Yurtiçi Hasılaya oranı gelişmekte olan ülkelerde $\% 41$, geçiş ekonomilerindeki ülkelerde \%38, Ekonomik Kalkınma ve İşbirliği Örgütüne üye ülkelerde ise \%18'dir. Gelişmiş ekonomiler olan 27 Avrupa Birliğgi ülkesinde kayıt dışı ekonominin GSYH'ye oranı \%18,4 iken, Avusturalya, Kanada, Japonya, Yeni Zelanda ve Amerika Birleşik Devletleri’nde bu oran \%8.6'dir (Schneider, 2013:25).

Kayıt dışı istihdamda para ödemelerinden vergi alınmaması, işçilik maliyetini düşürür ve emek talebini yani istihdamı artırır. Artan istihdam sonucu çalışanların gelirlerindeki yükseliş piyasada tüketimi ve yatırım mallarına olan talebi artırır. Dolasıyla gelir belirleyen değişkenlerde meydana gelen değişimin milli gelirde oluşturacağı katkıyı ölçmek için kullanılan çarpan mekanizması yoluyla da Gayri Safi Milli Hasıla yani milli gelir seviyesi yükselmiş olur. $\mathrm{Bu}$ durum kayıt dışı ekonomi ile GSMH arasındaki pozitif ilişkiyi gösterir (Uzunoğlu, 2006:146-147).

Kayıt dışı ekonomi ile büyüme arasındaki ilişkinin negatif göstergelerinin olduğu tezler olsa da genel görüş pozitif etkisinin olduğu 


\section{M.M.DAM - Ş.ERTEKIN - N.KIZILCA}

yönündedir. Çünkü kayıt dışındaki gelirlerin yarısından fazlasının kayıtlı sektörde harcanması ekonominin faal şekilde devamına ve doğrudan olmasa da vergilerin artışına katkı sağlamaktadır (Çetintaş ve Vergil, 2003:18-19). Kayıt dışı ekonominin resmi ekonomideki faaliyetlerini kısması kayıtlı ekonomide firmalar arasında rekabetin artmasına sebep olur. Ayrica elde edilen kayıt dışı gelirlerinin büyük bir kısmının ekonomide harcanması pozitif bir değer göstergesidir (Schneider ve Enste, 2000:87-88).

Küreselleşmeyle birlikte ekonomide yaşanan dönüşümler sonucu sanayileşen toplumlar, köyden kentlere doğru göçlere sebep olmuştur. $\mathrm{Bu}$ durum, kentlerde yüksek işsizlik oranlarını beraberinde getirmiştir. Yapılan bir çalışmada küreselleşmenin ortaya çıkardığı istihdam biçimleri, üretimin farklı yönlerinin dünya ölçeğinde yayılması, fason üretim, taşeron sisteminin ve esnek çalışmanın yaygınlaşması, kayıt dışı ve düşük ücretle çalışmayı yoğunlaştırdı ğı belirlenmiştir (İpek, 2014:181).

Mal ve işgücü piyasalarında kayıt dışı ekonomi istatistiklerini doğrulamak oldukça zordur. Çünkü bu piyasalarda yapılan tüm faaliyetler belirlenememektedir. Bu yüzden araştırmacılar kayıt dışı ekonomiyi tahmin etmek için birtakım yöntemler ve analizler kullanmaktadır (Schneider, 2002:2). Kayıt dışı istihdamın ülkelerin gelişmişlik düzeyleri göz önünde bulundurularak yapılan diğer bir çalışmada ise, gelişmiş ülkelerdeki işsizlik ve eksik istihdamın ekonomik büyümeyle azalırken, gelişmekte olan ülkelerde işsizlik ve eksik istihdamın ekonomik büyümeyle birlikte arttığı tespit edilmiştir (Chen, 2012:2).

\section{ANALIZ}

Bu konudaki metodolojiye baktığımızda, kayıt dışı istihdam verilerinin çok az olması ve bu verilerin güvenirliğinin tartışmaya açı olması yönüyle bu konuda az sayıda analizin olduğu görülmektedir. Türkiye Cumhuriyeti 
Sosyal Güvenlik Kurumunun, Türkiye İstatistik Kurumu (TÜİK) verilerinden derlediği 2002-2016 yılları istihdam verileri ile diğer makro ekonomik değişkenleri modele alarak bir analiz yapılmıştır. Kayıt dışı istihdam verilerinin kısa bir döneme ait olması analiz açısından bizi sinırlamaktadır.

\subsection{Veri Seti}

Çalışmada, Türkiye için 2002 - 2016 dönemlerini kapsayan veri seti yıllık olarak kayıt dışı istihdam oranı, ekonomik büyüme, işsizlik ve enflasyon oranı kullanılmıştır. Kayıt dışı istihdam oranı serisi Türkiye Cumhuriyet Sosyal Güvenlik Kurumu tarafindan TÜİK'in Hanehalkı İşgücü İstatistiklerinden derlenerek elde edilmiştir. Ekonomik büyüme serisi, işsizlik serisi (\% of total labor force) ve enflasyon serisi (GDP deflator, annual \%) oran olarak Dünya Bankası'ndan alınmıştır. Çalışmanın bundan sonraki bölümlerinde kayıt dışı istihdam serisi: EMP; ekonomik büyüme serisi: GDP, işsizlik serisi: UNP ve enflasyon serisi: INF diye ifade edilecektir.

\subsection{Model ve Yöntem}

$\mathrm{Bu}$ çalışmada ekonomik büyüme, işsizlik ve enflasyonun kayıt dişı istihdam üzerindeki etkisi zaman serisi yöntemiyle analiz edilmektedir. Model aşağıdaki şekilde tahmin edilmiştir.

$$
\mathrm{EMP}_{\mathrm{t}}=\alpha_{0}+\alpha_{1} \mathrm{GDP}_{\mathrm{t}}+\alpha_{2} \mathrm{UNP}_{\mathrm{t}}+\alpha_{3} \mathrm{INF}_{\mathrm{t}}+\varepsilon_{\mathrm{t}}
$$

Günümüzde $\alpha_{0}$ ve $\alpha_{1}$ parametrelerinin tahmini için kullanılan en yaygın yöntemlerden birisi en küçük kareler (EKK) yöntemidir. EKK yönteminin kullanıldığg çalışmada Türkiye için 2002-2016 dönemi yıllık verileri kullanılmıştır. Analiz için EViews 9 ekonometrik analiz programından yararlanılmıştır. 


\section{M.M.DAM - Ş.ERTEKIN - N.KIZILCA}

\subsection{Genişletilmiş Dickey-Fuller Birim Kök Testi}

Genişletilmiş Dickey-Fuller Birim Kök Testi Analizde sahte regresyonla karşılaşmamak için seriler durağan hale getirilir. Çünkü durağan olmayan serilerle yapılan analizlerde sahte regresyon yüzünden çıkan sonuçlar gerçek ilişkiyi yansıtmayabilir (Granger ve Newbold, 1974). Böyle bir sorunda t ve F test sonuçları tartışmalı hale gelir. Alınan serinin ortalaması ile varyansının zaman içinde sabit kalması ve kovaryansın iki dönem arasındaki uzaklığa bağlı kalması zaman serileri için durağan olmasında önemlidir (Gujarati, 2006:713).

$\mathrm{Bu}$ çalışmada, serilerin durağanlığını analiz etmek için Dickey-Fuller testi kullanılmıştır. $\mathrm{Bu}$ test, üç regresyon denklemi kullanılarak yapılmaktadır (Peker ve Bölükbaş, 2013:294):

Yalın hali:

$$
\Delta \mathrm{Y}=\beta \mathrm{Y}_{\mathrm{t}-1}+\mu_{\mathrm{t}}
$$

Sabit terimli:

$$
\Delta \mathrm{Y}=\alpha_{0}+\beta \mathrm{Y}_{\mathrm{t}-1}+\mu_{\mathrm{t}}
$$

Sabit terimli ve trendli:

$$
\Delta \mathrm{Y}=\alpha_{0}+\alpha_{1 \mathrm{t}}+\beta \mathrm{Y}_{\mathrm{t}-1}+\mu_{\mathrm{t}}
$$

Yapılan Dickey-Fuller testinde, istatistikler MacKinnon kritik değerleri ile karşılaştırılarak; sıfır hipotezi (H0: $\beta=0)$, alternatif hipoteze karşı (H1: $\beta \neq 0)$ sınanmıştır. H0 hipotezi serinin durağan olmadığını (birim köke sahip olduğunu), H1 hipotezi ise serinin durağan olduğunu ifade etmektedir. Hata terimini ifade eden ut içsel bağıntı sorunu olması halinde denklem şu şekilde düzenlenir:

$$
\Delta \mathrm{Y}=\alpha_{0}+\alpha_{1} \mathrm{t}+\beta \mathrm{X}_{\mathrm{t}-1}+\gamma_{\mathrm{i}} \sum_{i=1}^{m} \Delta Y_{\mathrm{t}-\mathrm{i}}+\mu_{\mathrm{t}}
$$


Denklemde, $\Delta$ fark operatörünü ve $m$ gecikme uzunluğunu göstermektedir. Modeldeki gecikme sayısı içsel bağıntısız modelin elde edilmesine bağlıdır. Literatürde bu metotla yapılan test Genişletilmiş Dickey-Fuller testi (ADF) olarak bilinmektedir. ADF testi, literatürde en çok kullanılan durağanlık testlerinden birisidir. ADF birim kök test sonuçları Tablo 5.1'de verilmiştir.

Tablo 5.1. ADF Birim Kök Testi Sonuçları

\begin{tabular}{|l|c|c|c|c|c|c|}
\hline Değişken & $\begin{array}{l}\text { Düzey } \\
\text { Değeri }\end{array}$ & $\begin{array}{l}\text { Olasılık } \\
\text { Değeri }\end{array}$ & 1.Fark & $\begin{array}{l}\text { Olasılık } \\
\text { Değeri }\end{array}$ & 2.Fark & $\begin{array}{l}\text { Olasılık } \\
\text { Değeri }\end{array}$ \\
\hline EMP & -0.07 & 0.93 & -2.57 & 0.12 & $-3.53^{* *}$ & 0.02 \\
\hline$G D P$ & -2.70 & 0.09 & $-4.02^{* *}$ & 0.01 & - & - \\
\hline$U N P$ & -3.50 & 0.02 & $-4.02^{* *}$ & 0.01 & - & - \\
\hline$I N F$ & -7.26 & $0.00^{*}$ & - & - & - & - \\
\hline
\end{tabular}

Not: Birim kök sınamasında $t$ istatistiği kriteri kullanılmıştır. *, ** ve *** sırasıyla \%1, \%5 ve \%10 anlamlılık düzeyinde serinin durağan olduğunu ifade etmektedir.

Yapılan ADF testi sonuçlarına göre enflasyon serisi düzeyde durağan çıkmıştır. Ekonomik büyüme ve işsizlik serileri birinci farkta durağan çıkarken; kayıt dışı istahdam serisi ikinci farkta durağan hale gelmiştir. Bu durumda seriler arasındaki etkileşimin boyutu, EKK yöntemiyle tahmin edilebilecektir.

\subsection{En Küçük Kareler Tahmin Sonuçları}

2002-2016 dönemi EKK yöntemi ile yapılan analizde elde edilen sonuçlar Tablo 5.2'de verilmiştir. Analiz sonucunda modelin tanısal test sonuçlarının başarılı olduğu görülmektedir. Bu bağlamda, White değişen varyans testi, Jarque-Bera normallik testi, Breusch-Godfrey ardışık bağımlılık testi ve Ramsey regresyonda model kurma hatası istatistiği kabul edilebilir düzeydedir. Tablo 5.2'den de izlenebileceği gibi, EKK yöntemi ile tahmin edilen katsayılar incelendiğinde işsizlik değişkenin katsayısı pozitif 


\section{M.M.DAM - Ş.ERTEKIN - N.KIZILCA}

ve istatistiksel olarak anlamlı bulunmuştur. Enflasyon değişkeni katsayısı pozitif ama istatiksel olarak anlamlı değildir. Diğer taraftan ekonomik büyüme değişkeninin katsayısı negatif olarak bulunmasına rağmen istatistiksel olarak anlamlı değildir. $\mathrm{Bu}$ sonuçlara göre işizlik bir birim arttığında kayıt dışı istihdam 0.4 birim artmaktadır. Diğer bir ifadeyle işsizlik değişkeninin kaytı dışı istihdam üzerinde anlamlı bir etkisi bulunmaktadir.

Tablo 5.2. EKK Tahmin Sonuçları

\begin{tabular}{|l|c|c|c|}
\hline Değişken & Katsayı & t istatistiği & Olasılık Değeri \\
\hline EMP(-1) & 0.97 & 22.72 & $0.00^{*}$ \\
\hline GDP & -0.01 & -0.30 & 0.76 \\
\hline UNP & 0.49 & 2.39 & $0.04^{*}$ \\
\hline INF & 0.04 & 0.76 & 0.46 \\
\hline C (Sabit) & -5.30 & -2.14 & 0.06 \\
\hline Tanısal Testler & 0.98 \\
\hline $\mathrm{R}^{2}$ & 0.98 \\
\hline Düzeltilmiş R ${ }^{2}$ & $202.38(0.00)$ \\
\hline F $_{\text {ist }}$ & 1.94 \\
\hline Durbin-Watson & $1.259(0.353)$ \\
\hline$\chi^{2}$ WDV & $1.622(0.444)$ \\
\hline$\chi^{2}$ JBN & $1.00(0.452)$ \\
\hline$\chi^{2}$ BGAB & $0.513(0.621)$ \\
\hline$\chi^{2}$ RRMKH &
\end{tabular}

Burada, $\chi^{2}$ WDV, $\chi^{2}$ JBN, $\chi^{2}$ BGAB, ve $\chi^{2}$ RRMKH sırasıyla White Değişen Varyans, Jarque-Bera Normallik Testi, Breusch-Godfrey Ardışık Bağımlılık, ve Ramsey Regresyonda Model Kurma Hatası istatistikleridir. $(*),(* *)$ ve $(* * *)$ sirasıly $\% 1, \% 5$ ve \%10'da anlamlılık düzeyini gösterir. Parantez içindeki değerler olasılık değerlerini vermektedir.

\section{SONUC VE DEĞERLENDİRME}

Kayıt dışı ekonomi ülkelerin üzerinde durması gereken en önemli ekonomik sorunlardan biridir. Bu sorunun sebepleri ve etkileri ülkelerin siyasi, ekonomik ve sosyal ve kültürel yapılarına göre farklılık arz etmektedir. Konuyu maliye ve iktisat bilim insanları da farklı açılardan ele almışlardır. Maliye alanında çalışanlar kayıt dışı ekonomiyi daha çok vergi ile ilişkilendirirken, iktisatçılar makroekonomik değişkenler üzerinde 
durmaktadır. Ancak ekonomik ve mali nedenlerin dışında, siyasal otorite ve hukuki düzeni de kayıt dışı ekonomi açısından önemlidir. Bu çalışmada; kayıt dışı ekonomi ve kayıt dışı istihdam ilişkisi makroekonomik değişkenlerle açıklanmaya çalışılmıştır. Makroekonomik değişkenler bazında ekonomik büyümeye kayıt dışı ekonominin etkisi önemlidir. Tam bir görüş birliği sağlanamamakla beraber hem olumlu hem de olumsuz etkilerinin olduğu tespit edilmiştir. Olumlu ya da olumsuz etkilere sebep olan faktörler göz önünde bulundurularak kayıt dışılıkla mücadelede farklı politikalar geliştirilmelidir. Bununla beraber kaynakların tasarruflu ve verimli şekilde kullanılması da hem vatandaşa teşvik hem de kamu harcamalarının finanse edilmesi için önemlidir. Kaynakları etkin ve verimli, ekonomiklik ilkelerine uygun olarak kullanmak gerekmektedir. Çünkü vergi mükelleflerin vergi algıları ve vergiye gönüllü uyumları ile kamu harcamaları arasında doğrusal bir ilişki vardır. Yani bireyler ödedikleri vergi gelirlerinin nasıl harcandığı, kamu idareleri tarafindan israf edilip edilmemesi ile vergiye uyum arasında paralel bir ilişki bulunmaktadır.

Kayıt dış1 istihdam Türkiye gibi gelişmekte olan ülkelerde genellikle gelir dağılımı adaletsizliği, yoksulluk, işgücü maliyetlerindeki artış, yüksek işsizlik oranı, bürokratik işlemlerin fazlalığı, etkin denetim yetersizliği ve bazı nedenlerle işgücü piyasasında problem olarak karşımıza çıkmaktadır. İstihdam için gerekli yatırım ve teşviklerin olması kayıt dışı ekonomiyi azaltıp kayıt dışı istihdam yerine kayıtlı istihdamı teşvik eder. İstihdamla vatandaşın mali, ekonomik ve sosyal yönden motive olması sosyal devlet için bir güç kazanımıdır. Azgelişmiş ülkeler için kayıt dışını, gelişmiş ülkeler seviyesine indirmek amaç olmalıdır. Yani kayıt dışı ekonomiyi tamamen ortadan kaldırmak imkânsız olsa da alınacak tedbirlerle makul seviyelere indirmek sürdürülebilir bir ekonomi için gereklidir. 


\section{M.M.DAM - Ş.ERTEKIN - N.KIZILCA}

Enformel sektörün gelişmesinin önemli adımlarından olan iş gücü piyasasındaki aksaklıklar da kayıt dışılığı artırmıştır. İşgücü piyasasındaki yüksek sigorta primleri ve yüksek vergi oranları işverenleri kayıt dışı istihdama yönelten önemli faktörlerdendir. Bu sebeple iş gücü piyasasında piyasa ücretinin oluşmasına engel kurumların 1slah edilmesi önemli bir adımdır. Sendikalar hem duruşlarını hem de izledikleri politikalarını gözden geçirmelidirler. Bunun için ücret üzerindeki bu yükler azaltılmalı kayıtlı ekonomik teşvik edilmelidir.

İşsizliği azaltmanın yollarından biri kayıt dışı istihdamla mücadele etmektir. Yapılan analizde de işsizliğin kayıt dışı istihdamı etkilediği görülmüştür. İşsizlik, ülkelerin en önemli sosyo-ekonomik sorunlarının başında gelmektedir. $\mathrm{Bu}$ nedenledir ki; kayıt dışı istihdamı azaltacak politikalar her dönem ülkelerin ekonomi politikalarının vazgeçilmez bir unsuru olmaktadır. Türkiye'de işsizlik 2017 TÜİK verilerine göre \%10,9 gibi yüksek bir oran çıkmıştır. Bu bağlamda Türkiye'nin işsizliği azaltacak istihdam politikalar üretmesi aynı zamanda kayıt dışı istihdamın da azalmasına pozitif katkı sağlayacaktır. Türkiye'deki kayıt dışı istihdamı birkaç nedenle açıklamak mümkün olmamakla birlikte, sosyal güvelik mevzuatı ve vergi mevzuatının, istihdam üzerindeki aşırı mali yükün, denetim ve koordinasyon eksikliği, kentleşme, göç, eğitim gibi ekonomik, hukuki ve sosyal nedenden kaynaklandığını söylenebilir. $\mathrm{Bu}$ analizde ekonomik boyut ele alınmış olup, kayıt dışı istihdam ile makro ekonomik değişkenler arasındaki ilişkiye incelenmiştir.

Yaptığımız analizde de 2002-2016 yılları arasında Türkiye ekonomisinde makro ekonomik değişken olan ekonomik büyüme, işsizlik ve enflasyon değişkenlerinin kayıt dışı istihdam üzerindeki etkisi incelenmiştir. EKK yöntemi ile tahmin edilen katsayılar incelendiğinde işsizlik değişkenin katsayısı pozitif ve istatistiksel olarak anlamlı bulunmuştur. Enflasyon 
değişkeni katsayısı pozitif olmasına rağman istatiksel olarak anlamlı değildir. Diğer taraftan ekonomik büyüme değişkeninin katsayısı negatif olarak bulunmasına rağmen istatistiksel olarak anlamlı değildir. $\mathrm{Bu}$ sonuçlara göre işizlik bir birim arttığında kayıt dışı istihdam 0.4 birim artmaktadır. Sonuç olarak ifadeyle işsizlik değişkeninin kayıt dışı istihdam üzerinde anlamlı bir etkisi bulunmaktadır.

Ülkemizde kayıt dışı ekonominin kayıtlı ekonomiye göre fazla vermesi veya tercih edilmesi zaten alınan tedbirlerin yeterli olmadığını göstermektedir. Bu sebeple kısa vadede kayıt dışı ekonomi sorunun çözümü mümkün görünmeyip, ancak uzun vadede çözülebilecek ekonomik ve sosyal bir olgu olduğu anlaşılmaktadır. Ülkemizde kayıt dışı ekonominin kayıtlı ekonomiye oranının üçte bire yaklaştığını istatistikler göstermektedir. 2017 TÜİK verilerine göre istihdam oranı \%48 olurken, kayıt dışı çalışanların oranı \%35,2 olarak gerçekleşmesi de bu savı doğrulamaktadır.

Bir ülkedeki kayıt dışı istihdam üzerinde ülkelerin siyasi, ekonomik, sosyal, idari ve mali yapılarının önemli etkileri bulunmaktadır. Bu sebeple kayıt dışı istihdamla mücadele ederken ülkelerin sahip oldukları siyasi, ekonomik ve mali yapısı ve kendi iç dinamikleri göz önünde bulundurularak politika geliştirilmelidir. Kayıt dışı istihdamın nedenleri arasındaki saydığımız istihdam üzerindeki aşırı sosyal güvenlik prim yükü ve vergi yükünün düşürülmesi gerekmektedir. Türkiye'de ücret düzeyinde vergi ve sigorta prim oranlarını düşürerek vergi ve sigorta alanı tabanda genişletilmelidir. Türkiye’de istenilen ve belirlenen düzeyde toplanacak vergilerle bütçe açıklarının kapanmasının yanı sıra eğitim, sağlık ve sosyal hizmet paylarının da artması sağlanabilir. Mükelleflerin vergi ve prim cezalarına sürekli af beklentisi düşüncesinin önüne geçilerek caydırıcılık kazandırılmalıdır. Vergi ve sosyal güvenlik mevzuatı tüm paydaşların anlayabileceği şekilde basitleştirilmeli ve işyeri açma ve sonraki süreçler 


\section{M.M.DAM - Ş.ERTEKIN - N.KIZILCA}

için bürokratik işlemler azaltılarak kayıt dışı istihdamı önlemede fayda sağlanabilir. Denetim organlarının birbirleriyle koordinasyonu sağlanıp farklı kamu kurum ve kuruluşlarla da iş birliği yapılarak kayıt dışı istihdam önlenebilir. Vergi kaçırma ve kayıt dışı istihdama karşı devlet, vatandaş ve STK'larla beraber çalışarak kayıt dışı sorununa daha hızlı çözümler bulunmalıdır. Özellikle çocuk işçi ve kayıt dışı işçi çalıştıranlara karşı sosyal güvenlik mevzuatında daha etkili ve uygulanabilir yaptırımlar getirilmelidir. Çocuk işçiliğinin önüne geçmek adına küçük yaşta çalışmaya başlayanların eğitim seviyesini artırmak için zorunlu temel eğitim uygulamasının denetiminin iyi yapılması gerekir.

\section{KAYNAKÇA}

AKALIN, G. ve KESİKOĞLU, F. (2007). Türkiye'de Kayıt D1şı Ekonomi ve Büyüme İlişkisi, Zonguldak Karaelmas Üniversitesi Sosyal Bilimler Dergisi, 3 (5).

AKGEYİK, T., YAVUZ, A., ERSÖZ H. Y., Özdemir S. ve Şenocak H. (2004). İstanbul'da Enformel Sektör, İşportacılar: Eminönü İlçesinde Bir Alan Araştırması", Erguvan Yayınevi, İstanbul.

ALTUĞ, O. (1999). Kayıt Dışı Ekonomi, Türkmen Kitabevi, İstanbul.

AYDEMİR, S. (1995). Türkiye'de Kayıt Dışı Ekonomi, Maliye Hesap Uzmanları Derneği, İstanbul.

BAĞIRZADE, E. (2012). Kayıt Dışı Ekonomi Kavramına Ortak Yaklaşım Sorunu: Makro-İktisat Kapsamlı Analiz, Hacettepe Üniversitesi PEGEM, Sosyo-Ekonomi Dergisi, 18 (18).

CANDAN M. (2007). Kayıt Dışı İstihdam, Yabancı Kaçak İşçi İstihdamı ve Toplumumuz Üzerindeki Sosyo-Ekonomik Etkileri TC. Çalışma ve Sosyal Güvenlik Bakanlığı Türkiye İş-Kur Genel Müdürlüğü, İstihdam ve Meslek Uzman Yardımcısı Uzmanlık Tezi, Ankara.

CHEN, M. A. (2012). The Informal Economy: Definitions, Theories and Policies, Women in Informal Employment Globalizing and Organizing (WIEGO) Working Paper, No: 1, August. 
ÇETINTAŞ, H. ve VERGIL， H. (2003). Türkiye'de Kayıt Dışı Ekonominin Tahmini, Doğuş Üniversitesi Dergisi, 4 (1).

FiDAN H. ve GENÇ S. (2013), Kayıt Dışı İstihdam Ve Kayıt Dışı İstihdama Etki Eden Mikro Faktörlerin Analizi: Türkiye Özel Sektör Örneği, Mehmet Akif Ersoy Üniversitesi Sosyal Bilimler Enstitüsü Dergisi, 5 (9).

GRANGER, C. W. J. and NEWBOLD, P. (1974). "Spurious regressions in econometrics". Journal of Econometrics 2, 111-120.

GUJARATI, D. N. (2006). Temel Ekonometri, Çev. Ümit Şenesen ve Gülay Göktürk Şenesen, Literatür Yayıncılık, İstanbul.

GÜLOĞLU T. (2005). The Realty of İnformal Emoployment in Turkey, İnternational Program Visiting Fellow Working Papers, Cornell University.

İPEK, M. (2014)., Kayıt Dıı̧ı İstihdamda Küresel Etkiler ve Sosyal Örüntüler, Çalışma ve Toplum Dergisi, Birleşik Metal İş Sendikası Yayını, 201481), Ankara.

KAMALIOĞLU N. Ç. (2014). Kayıt Dış1 İstihdam Ve Türkiye'de Uygulanan Mücadele Politikalarının Değerlendirmesi, Hacettepe Üniversitesi Sosyal Bilimler Enstitüsü Maliye ABD, Yayınlanmamış Yüksek Lisan Tezi.

KIZILOT Ş. ve ÇOMAKLI Ş. E. (2004). Vergi Kayıp ve Kaçaklarının Mevzuat Açısından Değerlendirilmesi, 19. Türkiye Maliye Sempozyumu, Antalya.

MAHIROĞULLARI A. (2017). Türkiye'de Kayıt Dışı İstihdam Ve Önlemeye Yönelik Stratejiler, Süleyman Demirel Üniversitesi İktisadi ve İdari Bilimler Fakültesi Dergisi, 22(2).

ÖNDER I. (2001). Kayı̀t Dışı Ekonomi Ve Vergileme, İstanbul Üniversitesi Siyasal Bilgiler Fakültesi Dergisi, No:23-24, İstanbul.

PEKER, O. ve BÖLÜKBAŞ, M. (2013). Türkiye'de Dış Borçlanmanın Belirleyicileri: Ekonometrik Bir Analiz, Atatürk Üniversitesi, İktisadi ve İdari Bilimler Fakültesi Dergisi, 27(2), 289-302. 


\section{M.M.DAM - Ş.ERTEKIN - N.KIZILCA}

SARILI M. A. (2002). Türkiye'de Kayıt dışı Ekonominin Boyutları, Nedenleri, Etkileri ve Alınması Gereken Tedbirler, Bankacilar Dergisi, S.41.

SCHNEIDER, F. (2002). Size and Measurement of the Informal Economy in 110 Countries around the World, Workshop of Australian National Tax Centre, ANU, Canberra, Australia.

SCHNEIDER, F. (2013). Size and development of the shadow economy of 31 European and 5 other OECD countries from 2003 to 2013: A further decline.

(Erişim:20.01.2014)

http://www.econ.jku.at/members/Schneider/files/publications/2013/ShadEc

Europe31_Jan2013.pdf.

SCHNEIDER, F. and ENSTE D.H. (2000). "Shadow Economies: Size Causes and Consequences”, Journal of Economic Literature.

SCHNIDER, F. and KLINGLMAIR, R. (2004). Shadow Economies Around The World: What Do We Know? Center for Research in Economics, Management and the Arts, Working Paper. 2004-03.

SOSYAL GÜVENLİK KURUMU (SGK), (2017). http://www.sgk.gov.tr/wps/portal/sgk/tr/ (03.12.2017).

US, V. (2004). Kayıt Dışı Ekonomi Tahmini Yöntem Önerisi: Türkiye Örneği Türkiye Ekonomi Kurumu Tartışma Metni 2004/17, http://www.tek.org.tr/dosyalar/VUSLAT-US1-KAYITDISI.pdf (Erişim: 10.03.2018).

UZUNOĞLU, S. (2006). "Kayıt Dışı Sorun mu Yoksa Çıkış Yolu mu?”, Y1l:11, sayı:41.

YILMAZ, G. A. (2006). Kayıt Dışı Ekonomi ve Çözüm Yolları, Toplumsal Raporlar 7, İstanbul Serbest Muhasebeci Mali Müşavirler Odası, İstanbul. 